\title{
The Relationship Between Parenting Patterns and Providing Information On Adolescent Reproductive Health At SMA Negeri 3 Pematangsiantar
}

\author{
lis May Dwi Mulyana \\ Sumatera Utara Faculty Of Nursing \\ E-mail: iismaydwi@gmail.com
}

\begin{abstract}
Adolescence is often called the period of puberty where adolescents have a strong desire to know many new things, especially about reproductive health. The role of parents through the applied parenting is very necessary in providing information related to reproductive health. However, parents often consider it taboo if teenagers ask questions related to reproductive health so that teenagers will seek the information they need from irresponsible sources that allow them to adapt their deviant behavior. This study aims to identify the relationship between parenting and providing information about adolescent reproductive health at SMA Negeri 3 Pematangsiantar. This study used a cross sectional design. The sample of this research is 79 students. Sampling used proportional stratified random sampling and simple random sampling. The results of this study indicate that the parenting style that tends to be applied by adolescent parents is democratic (92.4\%) with the provision of information about adolescent reproductive health in the good category $(73.4 \%)$. The results of the analysis of the relationship between parenting and providing information about adolescent reproductive health measured by the Pearson product moment test indicate that parenting applied by parents has an important role in providing information to adolescents about adolescent reproductive health with a p value of $0.00(\alpha<0.05)$ and correlation $(r)=0.420$
\end{abstract}

Keywords: Adolescent Reproductive Health, Providing Information, Parenting

\section{Introduction}

Adolescence is often called the period of puberty where teenagers have a strong desire to know many new things, especially about the changes that occur in themselves. Teenagers tend to want to explore everything and try everything that has never been experienced before. This desire is driven by the desire to be like an adult which causes teenagers to want to try to do what adults often do, including those related to sexuality problems (Azwar A, 2000: in Azinar, 2013). Lack of comprehensive reproductive health information, education, and services that are not available to adolescents can make them prefer to seek answers to their questions from various sources that allow adolescents to adapt habits, such as drug abuse.

The results of research from the Indonesian Adolescent Reproductive Health Survey Institute (SKRRI) (2007: in BKKBN, 2012) show that unmarried adolescents, both girls and boys aged 15-24 years, stated that they had had premarital sexual relations, $1 \%$ each in women and $6 \%$ in men and the experience of teenagers in dating in Indonesia holding hands with $69 \%$ boys and $68.3 \%$ girls, kissing $41.2 \%$ boys and $29.3 \%$ girls and touching/ stimulated $26.5 \%$ boys and $9.1 \%$ girls. The results of the Indonesian Demographic and Health Survey (IDHS, 2012) regarding adolescent reproductive health show that adolescents' knowledge of reproductive health is only $35.5 \%$ female adolescents and $31,2 \%$ of teenage boys aged $15-19$ years know that a woman can get pregnant with one sexual intercourse and information on comprehensive knowledge about HIV/AIDS is relative to $9.9 \%$ of girls and $10.6 \%$ of boys. Premarital sexual behavior among adolescents is reinforced by data from the Ministry of Health in 2009 in 4 major cities namely Medan, Central Jakarta, Bandung, and Surabaya, showing that $35.9 \%$ of adolescents have friends who have had premarital sex and $6.9 \%$ of respondents have had premarital sex (BKKBN, 2012). Drug abuse by education level based on data from the National Narcotics Agency in the period 2008-2012 it was noted that the largest proportion of drug suspects had a high school background (Primadi, 2014).

Pematangsiantar is the second largest city in North Sumatra and an educational city that is a destination for teenagers from other regions, especially Simalungun Regency to be able to taste education 
in this city. With the development of the times, Pematangsiantar city has experienced a shift in the value of adolescent sexual behavior and an increase in delinquency in premarital sexual behavior.

This is indicated by the number of teenage couples in school uniforms hanging around with their girlfriends after school, and it is not uncommon for the Civil Service Police to catch teenage couples in school uniforms hanging around during study hours (Saragih, 2015).

\section{Method}

This study uses a quantitative method with a cross-sectional design, namely research on independent and dependent variables studied at the same time which aims to determine the relationship between parenting and providing information about adolescent reproductive health in SMA Negeri 3 Pematangsiantar.

The data collection instrument in this study used a questionnaire that contained several statements in the form of a questionnaire and was given directly to the respondents. The questionnaire used consists of three parts, the first (part A) demographic data to see the demographic distribution of the respondents and not analyzed, the second (part B) for the parenting style variable which is a new instrument consisting of 10 statements of authoritarian parenting. , 10 statements of permissive parenting, and 10 statements of democratic parenting where all statements are the result of modified questions from Paramitha (2014) in his book entitled "INIKAH AKU? Fun Way to Know and Understand Yourself". The type of statement is a statement using the answer choices always (SL), often (SR), sometimes (KD), never (TP).

Validity or validity is an index that shows the measuring instrument or research instrument actually measures what is being measured. The validity test used in this study is content validity on the parenting style instrument as many as 30 statements modified by researchers and validated by a lecturer at the USU Faculty of Nursing from the Community Nursing Department, namely Mrs. Lufthiani, S.Kep, Ns, M.Kes as well as the instrument for providing information on adolescent reproductive health which was made by the researcher himself and was validated by a lecturer at the USU Faculty of Nursing from the Maternity Department, namely Ibu Erniyati, S.Kp, MNS. The value of the validity of the parenting style questionnaire is 0.824 and the questionnaire providing information about adolescent reproductive health is 0.811 , so it can be said that the instrument is valid.

\section{Analysis And Results}

The results of this study indicate that the majority of respondents at SMA Negeri 3 Pematangsiantar have parents with a tendency to apply democratic parenting, namely 73 people (92.4\%) with the father's occupation being the majority of entrepreneurs as many as 35 people (44.3\%) and the mother's occupation being housewives. stairs as many as 27 people (34.2\%). This shows that teenagers get good treatment from parents at home who prioritize the condition of their children through rational thinking or attitudes in educating children.

The results of this study are supported by the results of research by Sipahutar (2009) regarding the relationship between parenting patterns and the level of adolescent alcohol consumption habits in Sirajaoloan Village, Tarutung District, North Tapanuli Regency. 43\% with the work characteristics of the majority of parents as farmers as many as 23 people (54.77\%).

In Silalahi's research (2014) with the title The Effect of Family Parenting Patterns on Student Achievement in Rantau Selatan Subdistrict, Labuhan Batu Regency in 2013 showed that the majority of parenting applied tended to be democratic as many as 22 people (63\%) with the majority of the job characteristics of parents being as follows: self-employed as many as 15 people (43\%).

The results of Teviana and Yusiana's (2012) research on Parenting Parenting on Children's Creativity Levels show the tendency of parents to apply democratic parenting as many as 38 people (57.6\%) of 66 respondents with the majority of parents' occupations being entrepreneurs as many as 52 people $(78,8 \%)$.

Santrock (2007; in Marlina, 2014) suggests that the ideal parenting style to be applied is democratic parenting. This is because democratic parents provide opportunities for children to form independence and provide appropriate standards, boundaries, and guidelines that children need; more likely to involve children in verbal give and take activities and allow children to express their views; and the warmth and involvement of democratic parents make children more receptive to parental influence.

In contrast to the research conducted by Wildan (2010) in his research entitled The Effect of Parenting Parenting and Peer Groups on Adolescent Self-Concept regarding Sexual Behavior in SMA Negeri 2 and MAN 2 Medan in 2012 that parenting patterns in SMA Negeri 2 were found mostly Authoritarian parenting as many as 42 people (56.8\%) and parenting at MAN 2 Medan also found the majority of authoritarian 
parenting as many as 50 people (67.6\%) with the characteristics of the father's work being the majority of civil servants as many as 36 people $(48,6 \%)$ and the occupation of the mother, the majority of whom are housewives, are 24 people (32.4\%).

The results of Melissa Sidabutar's research (2016) on the Relationship between Parenting Parenting Patterns and Juvenile Delinquency at Ar-Rahman Private High School Medan also showed that the parenting style that parents tend to apply is authoritarian as many as 33 people (50\%), the remaining 23 people (34.8\%) tend to be democratic and 10 people (15.2\%) tend to be permissive with the majority of the job characteristics of parents being entrepreneurs as many as 39 people (59.1\%).

In Saputra's research (2012) concerning the Relationship between Parenting Parenting Patterns with Aggressive Behavior in Adolescents at SMA Gadjah Mada Yogyakarta, it shows that the majority of parenting applied by parents tends to be authoritarian, as many as 19 respondents (38.8\%), followed by respondents with parenting style. parents tend to be permissive as many as 17 respondents (34.8\%) and as many as 13 respondents (26.5\%) with parenting patterns tend to be democratic.

Parenting patterns are influenced by various factors, one of which is the work of parents (Dewi, 2014). In this study, the majority of the father's work is an entrepreneur, while the mother's work is housewife and the parenting style applied tends to be democratic.

Many parents, especially fathers who work as entrepreneurs, do not have free time to interact with their children where work as entrepreneurs spend more free time outside until the afternoon or evening, while mothers as housewives certainly have a lot of free time in interacting with their children. (Dewi, 2014). When viewed from the perspective of father's work, it is impossible for parents to have a democratic parenting style. However, when viewed from the perspective of the mother's work, who is more often at home, it is possible that the parenting style applied tends to be democratic. This is due to the role of the mother at home.

Some of the results of the research above, it was found that the work of the father is the majority of civil servants and the work of the mother is the majority of the housewives, but the parenting style applied tends to be authoritarian. This can happen because there are still various factors that might affect the application of parenting at home.

According to Clemes (2001; in Rahman, 2012) that if their child is guilty they will be immediately given punishment and firm action. There are also those who use the pattern of gentleness and affection. Each parent has its own parenting style in directing their children. This is influenced by the background of parents, customs, socio-economic conditions and so on. Therefore, we cannot judge that democratic parenting is better than other parenting styles. However, it depends on how children respond to what their parents do is for their own good and how parents apply appropriate parenting styles to their children.

In this study, based on the data collected, it was found that the majority of parents in providing information about adolescent reproductive health given by parents to adolescents was in the good category $(73.4 \%)$.

These results are in line with the results of research conducted by Muslichah and Hilman (2008) entitled The Effect of Parental and Adolescent Relationships on Knowledge of Behavioral Attitudes about Free Sex and Drugs, showing that the role of parents in adolescent reproductive health education was obtained from 115 respondents, obtained 79 respondents. (68.7\%) included in the good category.

Jumiatum's (2014) research on the relationship between Parental Education on Adolescent Reproductive Health and Out-of-Marriage Pregnancy in Sukomulyo Village found that the majority of respondents explained that reproductive health education was good as many as 25 people (56.8\%).

The results of this study are not in accordance with the results of research by Utami (2013) with the title Relation of the Role of Parents in Reproductive Health Education with Menstrual Hygiene Behavior in seventh grade students of SMP Negeri 3 Pajanan Bantul Yogyakarta that the role of parents in reproductive health education is $60.0 \%$ ( 24 female students) were categorized as poor and the remaining 40.0\% (16 female students) already had the role of parents in good reproductive health education.

In this case, parents through parenting applied at home to adolescents, when children or adolescents begin to be interested in information related to adolescent reproductive health and parents accept this interest, then that is when parents must provide the information. So that teenagers will avoid deviant sexual behavior.

The result of the $r$ value of democratic parenting is 0.580 , which means that respondents with democratic parenting $(p=0.000)$ play a very important role in providing information on adolescent reproductive health. The better the democratic parenting style applied, the better the information on adolescent reproductive health provided by their parents. Compared with permissive parenting $r=-0.079$ and authoritarian parenting $r=0.045(p=0.691)$, which means that the more frequent the permissive 
parenting pattern is, the less information conveyed by parents regarding adolescent reproductive health and the more often authoritarian parenting is applied, then the better the reproductive health information provided. However, when viewed from the $p$ value of authoritarian parenting $(p=0.691)$ and permissive parenting $(p=0.489)$ where $<0.05$, the relationship is not significant. According to Azwar (2005), insignificant means the statistical price should be ignored. So that researchers ignore the relationship between authoritarian and permissive parenting on the provision of information about adolescent reproductive health.

\section{Conclusion}

Based on the results of research conducted on 79 respondents at SMA Negeri 3 Pematangsiantar that the parenting pattern most widely used by the respondent's parents was democratic parenting as many as 73 respondents, and providing information about reproductive health given by parents to the majority of respondents in the good category as many as 58 respondents.

The results of the Pearson Product Moment test obtained a significance value $(p=0.000)<0.05$ with a value of $r=0.420$ then $\mathrm{Ho}$ is rejected and $\mathrm{Ha}$ is accepted, so there is a significant relationship between parenting patterns and providing information about reproductive health where parenting is applied. by parents have an important role in providing information to adolescents about adolescent reproductive health.

\section{References}

Azinar, M. (2013). Risky Premarital Sexual Behavior towards Unwanted Pregnancy. Public Health 8, 2, 153-160.

Azmi, F. (2015). The Relationship of Parenting Patterns with Adolescent Sexual Behavior at SMAN 1 Sanden Bantul. Thesis, College of Health Sciences Aisyiyah, Yogyakarta.

Azwar, S. (2005). Significant or Very Significant. UGM Psychology Bulletin, 13, 39-44.

[BKKBN] National Population and Family Planning Agency, Directorate of Youth Resilience Development. (2012). Effective Communication of Parents and Adolescents. Jakarta: Directorate of Youth Resilience Development.

. (2012). Guidelines for the Management of Youth Family Development (BKR).

Jakarta: Directorate of Youth Resilience Development.

Dewi, EU (2014). Factors Affecting Parenting Parenting for Waria in Kembang Kuning Surabaya. Stikes Journal of William Booth, 3, 1.

Ekasari, F. (2007). Pattern of Reproductive Health Communication and Information between Fathers and Adolescents. National Journal of Public Health, 2, 26-32.

Fuadi, A. (2012). The Relationship between Perceptions of Democratic Parenting Patterns of Parents and Interpersonal Communication between Adolescents and Parents. Thesis, University of Muhammadiyah Surakarta, Faculty of Psychology, Surakarta.

Hardisman, (2014). Introduction to Reproductive Health, Sexology and Embryology in the Study of Medicine and the Qur'an. Yogyakarta: Gosyen Publishing.

Hendryadi. (2014). Content Validity (Content Validity). Theory online Personal Paper, 1, 1-5.

Herlina. and Zuhri, S. (2008). Parental Sex Education Model for Teenagers to Prevent Pre-Marriage Sex and Alternative Sexuality Impression Models. Journal of the Social Sciences, 8, 17-30.

Hidayah, NFN and Maryatun. (2013). Relationship between Parenting Parenting Patterns with Premarital Sexual Behavior in Adolescents at SMK Batik 1 Surakarta. GASTER, 10, 53-61.

Friday. (2014). Relationship of Parental Education on Reproductive Health in Adolescents with Out-of-Marriage Pregnancy in Sukomulyo Village. Journal of Health Sciences, 4, 1-5. 
Kusmiran, E. (2011). Reproductive Health of Adolescents and Women. Jakarta: Salemba Medika.

Marlina, I. (2014). The Effect of Parenting Parenting on Emotional Intelligence of Fifth Grade Elementary School Students in Cluster II, Umbulharjo District, Yogyakarta. Thesis, University of Yogyakarta, Faculty of Education, Yogyakarta.

Maryati, I., Asrori. and Donatian. (2012). Parenting Patterns for Social Behavior of Adolescents in Arang Limbung Village, Sungai Raya District, Kubu Raya Regency. Thesis, Tanjungpura University, Master of Social Sciences, Pontianak.

Meilani, N., Shaluhiyah, Z. and Suryoputro, A. (2014). Mother's Behavior in Providing Sexuality Education in Early Adolescents. Journal of Public Health, 8, 411-417.

Muinah. (2011). Analysis of the Effect of Income Level and Community Education Level on Demand for Life Insurance Products with Bumiputera 1912 Medan Regional Office. Final Project, University of North Sumatra, Faculty of Mathematics and Natural Sciences, Medan.

Muslichah, M. and Hilman, O. (2008). The Effect of Parental and Adolescent Relationships on Knowledge of Behavioral Attitudes about Free Sex and Drugs. Mutiara Medika, 8, 83-88.

Noor, J. (2011). Research Methodology: Thesis, Thesis, Dissertation, and Scientific Work. Jakarta: Prenada Media.

Notoatmodjo. (2012). Health Research Methodology. Jakarta: PT RINEKA CIPTA.

Paramitha, E. (2014). Is this me? Fun Way to Know and Understand Yourself.

Surabaya: Rona Publishing.

Poltekkes Ministry of Health Jakarta. (2010). Youth Health: Problems and Solutions. Jakartal: Salemba Medika.

Primadi, O. (2014). "Drug Users Can Be Prevented and Can Be Rehabilitated”, Bakti Husada, ISSN 2088-270X.

Putri, ADYD (2011). The Relationship of the Role of Parents in Providing Reproductive Health Education with Genital Organ Hygiene Treatment for Young Women in Tumut Sumbersari Moyudan Yogykarta Hamlet. Thesis, Aisyiyah College of Health Sciences, Nursing Science Study Program, Yogyakarta.

Rahman, PL (2012). The Relationship of Parenting Patterns in Coastal Communities. Thesis, University of North Sumatra, Faculty of Psychology, Medan.

Sagala, DN (2009). The Effect of Providing Information Regarding Job Prospects on Student Motivation in Nursing Study Program Path A, Faculty of Medicine, University of North Sumatra. Thesis, University of North Sumatra, Nursing Science Program, Medan.

Saputra, F. (2012). Relationship between Parenting Parenting and Aggressive Behavior in Adolescents at SMA Gadjah Mada Yogyakarta. Thesis, Aisyiyah College of Health Sciences, Nursing Science Study Program, Yogyakarta.

Saragih, DO (2015). Factors Related to Premarital Sexual Behavior of Adolescents at SMA Negeri 5 Pematangsiantar in 2015. Thesis, University of North Sumatra, Faculty of Public Health, Medan.

Sari, KP (2010). Knowledge of Reproductive Health in terms of the Perception of the Quality of Communication between Parents and Adolescents. Thesis, Sunan Kalijaga State Islamic University, Yogyakarta, Yogyakarta.

Saryono. (2011). Health Research Methodology Practical Guide for Beginners. Yogyakarta: Mitra Cendikia Press.

[IDHS] Indonesian Demographic and Health Survey, Central Bureau of Statistics. (2012). Adolescent Reproductive Health. Jakarta: Central Bureau of Statistics.

Sentosa, F. (2010). Level of Knowledge of Students of SMK Negeri 1 Medan on Adolescent Reproductive Health in 2010. Scientific Writing, University of North Sumatra, Faculty of Medicine, Medan.

Sidabutar, M. (2016). Relationship between Parenting Parenting and Juvenile Delinquency at Ar-Rahman Private High School Medan. Thesis, University of North Sumatra, Faculty of Nursing, Medan. 
Silalahi, YN (2014). The Influence of Family Parenting Patterns on Student Achievement in Class XI at SMA Negeri 2 Rantau Selatan, Rantau Selatan District, Labuhan Batu Regency 2013. Thesis, University of North Sumatra, Faculty of Nursing, Medan.

Sipahutar, A. (2009). Relationship between Parenting Parenting Patterns and Adolescent Habits in Consuming Alcohol in Sirajaoloan Village, Tarutung District, North Tapanuli Regency. Thesis, University of North Sumatra, Faculty of Nursing, Medan.

Siregar, AR (2012). Teenager. Medan: Faculty of Psychology, University of North Sumatra.

Siregar, AA (2014). Sex Education by Parents in Late Adolescence. Thesis, State Islamic University Sunan Kalijaga Yogyakarta, Faculty of Social Sciences and Humanities, Yogyakarta.

Sugiyono. (2011). Statistics for Research. Bandung: ALFABETA.

Teviana, F., and Yusiana, MA (2012). Parenting Patterns on Children's Creativity Levels. Journal of STIKES, 5, 48-60.

Tridhonanto, Al. (2014). Developing Democratic Parenting. Jakarta: PT Gramedia.

Utami, OWP (2013). The Relationship of the Role of Parents in Reproductive Health Education with Menstrual Hygiene Behavior in Class VII Students of SMP Negeri 3 Pajangan Bantul Yogyakarta. Final Project, STIKES, Study Program for Midwife Educators at Level D IV, Yogyakarta.

Wildan. (2013). The Influence of Parenting Parenting and Peer Groups on Adolescent Self-Concept regarding Sexual Behavior in SMA Negeri 2 and MAN 2 Medan in 2012. Thesis, University of North Sumatra, Masters Program in Public Health Sciences, Medan. 